\title{
Поздне- и послеледниковые разломы и палеосейсмонарушения в восточной части Фенноскандинавского щита: обзор и результаты исследований
}

\author{
Николаева С.Б. ${ }^{1}$, Никонов А.А. ${ }^{2}$, Шварев С.В. ${ }^{3,2}$ \\ ${ }^{1}$ Геологический Институт КНЦ РАН, Anamumbl, nikolaeva@geoksc.apatity.ru \\ ${ }^{2}$ Институт физики Земли им. О.Ю. Шмидта РАН, Москва, nikonov@ifz.ru \\ ${ }^{3}$ Институт географии РАН, Москва, shvarev@igras.ru
}

\begin{abstract}
Аннотация. Представлены результаты изучения поздне- и послеледниковых разломов и палеосейсмодислокаций в российской части Фенноскандинавского щита (Кольский полуостров, Карелия, Ленинградская область). Исследования осуществлялись на непротяженных разломах (или их участках), в основном реактивированным по зонам древних разломов. Выбраны структуры, задокументированные геологическими, геоморфологическими, реже геофизическими методами с различной степенью детализации. Полученные данные позволили установить снижение сейсмической активности от позднеледниковья к настоящему времени, что связано с затухающим гляциоизостатическим поднятием щита и переходом ведущей роли от вертикально направленных сил гляциоизостазии к латерально направленным воздействиям.
\end{abstract}

Ключевые слова: позднеледниковые разломы, послеледниковые разломы, палеосейсмичность, Кольский полуостров, Карелия, Ленинградская область.

\section{Late- and postglacial faults in the eastern part of the Fennoscandinavian Shield: review and research results}

\author{
Nikolaeva S.B. ${ }^{1}$, Nikonov A.A. ${ }^{2}$, Shvarev S.V. ${ }^{3,2}$ \\ ${ }^{1}$ Geological Institute of Kola Science Center RAS, Apatity,nikolaeva@geoksc.apatity.ru \\ ${ }^{2}$ Schmidt Institute of Physics of the Earth of RAS, Moscow,nikonov@ifz.ru \\ ${ }^{3}$ Institute of Geography RAS, Schmidt Institute of Physics of the Earth of RAS, Moscow, shvarev@igras.ru
}

\begin{abstract}
Results of studying late- and postglacial faults and paleoseismic dislocations in the Russian part of the Fennoscandian Shield (Kola Peninsula, Karelia, St. Petersburg region) are provided. Special investigations were carried out at small short postglacial faults and more often at their particular sections. Postglacial faults located in old reactivated fault zones in crystalline rocks. The study objects were structures registered using geological, geomorphological and rarely geophysical methods with different level of detail. The obtained data allowed defining a decrease in seismic activity from the Late Glaciation to the present times. It is due to the fading glacial isostatic uplift of the shield and the change of the leading role from the vertically directed forces of glacial isostacy to horizontal compressive forses.
\end{abstract}

Key words: lateglacial faults, postglacial faults; palaeoseismicity, Kola Peninsula, Karelia, St. Petersburg region.

\section{Введение}

Восточная, российская часть Фенноскандинавского кристаллического щита, (ФСКЩ), включающая Кольский полуостров (КП), Карелию и часть Ленинградской области, имеет, по меньшей мере, два важных отличия от остальной, большей части. Во-первых, это в несколько раз меньше скорости и, соответственно, величины поздне- и послеледникового поднятия. Второе, не менее важное с точки зрения изучения послеледниковых разломов, отличие заключается в развитии на востоке нескольких крупных грабенов древнего заложения, но активных в новейшее и четвертичное время, вплоть до современности. К ним относятся Кандалакшский, Онежский и Ладожский грабены. Их впадины заполнены обширными водными бассейнами, которые скрывают как главные активные разломы, так и более мелкие озерные впадины, также во многом предопределенные молодыми дифференцированными тектоническими движениями. Из-за выделенных особых тектонических и ландшафтно-географических условий большая часть крупных, разломов находятся под водами внутренних бассейнов. Поэтому специализированные исследования могли осуществляться на разломах 
коротких, а чаще на их ограниченных участках. Ввиду невозможности целенаправленного бурения глубинная структура разлома и зон разломов оставалась все же невыясненной. Частично, на отдельных участках и/или по отдельным профилям, удавалось привлечь буровые данные разных лет и организаций, остававшиеся неизвестными или не интерпретированными в тектоническом отношении.

\section{Краткий обзор и результаты исследований}

О проявлениях поздне-послеледниковой активности в восточной части ФСКЩ щита известно из работ П.Н. Мурзаева (1935), Н.Н. Карпова (1960), И. В. Буссен (1964), А.А. Никонова (1964), А.Д. Арманд и Н.Н. Арманд (1966), Б.И. Кошечкина (1979), Г.С. Бискэ (1966, 1970, 1971), Г.Ц. Лака (1974) и Г.Ц. Лака и А.Д. Лукашова (1967) и многих других. Все эти исследователи обращали внимание на смещения моренных гряд, нарушение уровней поздне- и послеледниковых террас на противоположных бортах долин рек, перекосы озерных котловин, мелкие послеледниковые расколы в фундаменте. Такие наблюдения были единичны, возраст разломов почти не определялся. С развитием в последнее десятилетие исследований по палеосейсмичности ФСКЩ, информация о поздне- и послеледниковых проявлениях в рельефе и отложениях значительно пополнилась. Для изучения голоценовых разломов стали привлекаться, наряду с геолого-геоморфологическими и геофизическими данными, современными методами дистанционного зондирования, и группа данных по палеосейсмодислокациям. Эта группа включала наблюдения и количественные измерения сейсмодислокаций с возрастом в несколько тысяч лет в зонах разломов - в коренных породах фундамента и в четвертичных осадочных образованиях (простирание, наклон, кинематика, величины смещений с последующими оценками интенсивности и магнитуды землетрясения и позиции очага). На ключевых участках собранные воедино сведения позволяли характеризовать если не разлом в целом, то его участок разносторонне, в том числе в позднеледниковье и в голоцене. В результате таких подходов были получены не только дополнительные сведения об активных разрывных структурах или их участках, но и о возрасте их активизации.

Из наиболее крупных (протяженностью более 100 км) выделяются две главные зоны разломов, ограничивающие Кольский полуостров и севера и юга. Это сбросо-сдвиг, известный как линеамент «Карпинского», разграничивающий Баренцевоморскую плиту и ФСКЩ и сбросы - сбрососдвиги Кандалакшского грабена в Беломорском бассейне на юге. Разломы были заложены в докембрии и неоднократно оживлялись в последующие эпохи тектонической активизации, в том числе и в голоцене.

Основная сейсмоактивная структура на востоке ФСКЩ - Кандалакшская сейсмогенная зона с новейшим Кандалакшским грабеном Белого моря и с сильнейшим из известных на платформе землетрясением 1627 года (Землетрясения..., 2007). Проявления голоценовой тектоники обнаружены как в рельефе дна Кандалакшского залива, так и на прилегающих к нему побережьях (Авенариус, 2007; Верзилин, Бобков, 2009). Данные сейсмического профилирования показывают, что смещения поверхностей, сложенных голоценовыми осадками, по плоскостям тектонических разрывов достигают первых метров (в отдельных случаях до 10-12 м) (Рыбалко, Корнеев, 2014). Преобладающие тектонические смещения в зоне Кандалакшского и Колвицкого грабенов вертикальны. Это отражается в высотах уступов по обрамлению грабенов до 100-150 м при суммарном опускании дна в осевой части Кандалакшского залива $\geq 300$ м. Хорошо заметны и сдвиговые смещения (Балуев и др., 2012). В качестве основного сейсмогенерирующего разрыва рассматривается сбросо-сдвиг молодого Колвицкого грабена и оперяющие его разрывные нарушения меньших масштабов, к которым приурочены различные типы сейсмодислокаций, в том числе и голоценовые. Наши исследования показали, что голоценовые сейсмодислокации наблюдаются не только на побережьях и на островах, но и на значительном удалении от берега.

Мурманская сейсмогенная зона в виде системы тектонических уступов протягивается на сотни км от полуострова Варангер на западе и далее на восток вдоль всего берега Кольского полуострова (рис. 1). На суше в морфоструктурном плане разлом выражен ступенями рельефа, долинами и каньонами, а в акватории - ступенями подводного рельефа. К этой тектонической зоне приурочена 


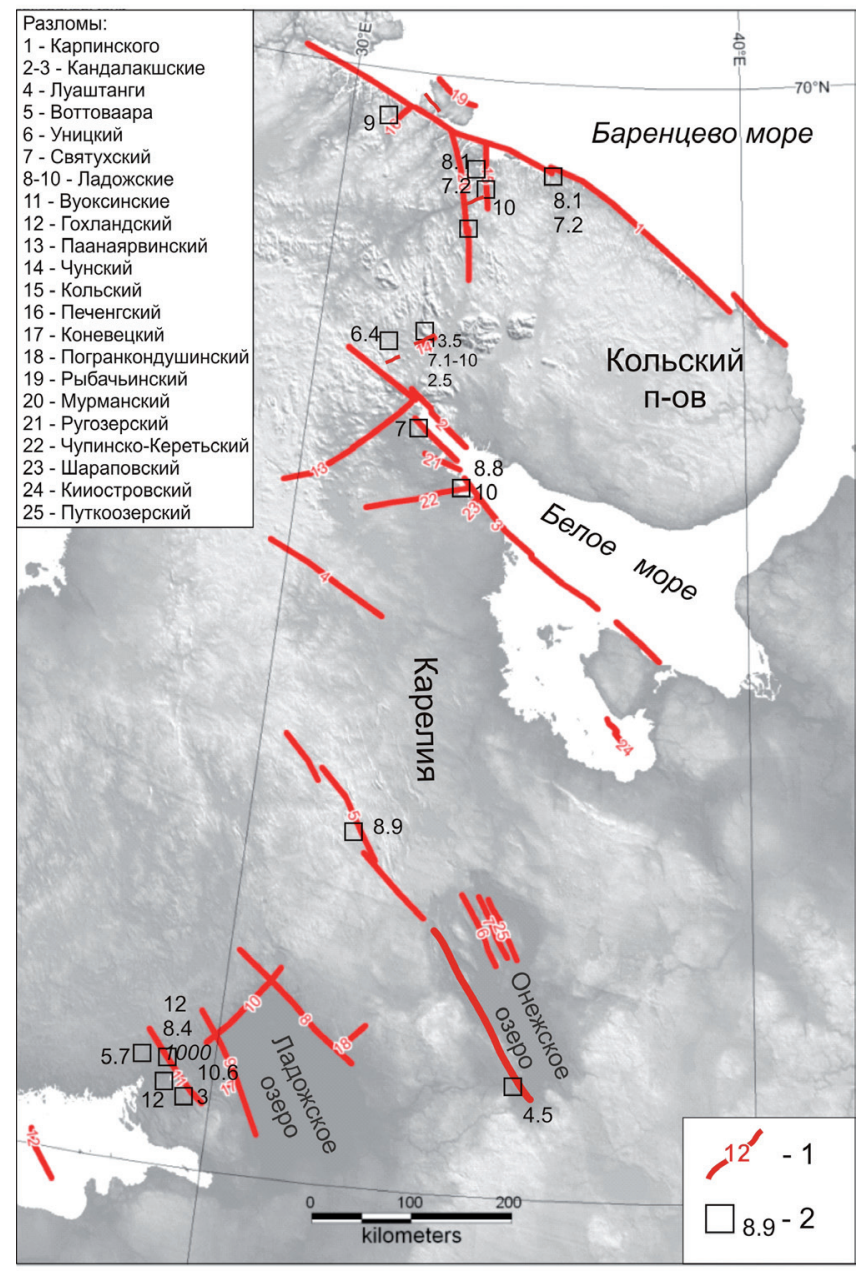

Рис. 1. Разломы с проявлением поздне-послеледниковой активизации и участки изучения палеосейсмодислокаций в восточной части ФСКЩ.

1 - активные разломы, 2 - участки изучения палеосейсмодислокаций. Цифрами указан калиброванный возраст в тыс. лет.

Fig. 1. Late- and postglacial faults and study areas of paleoseismic dislocations in the eastern part of the Fennoscandian Shield.

1 - active faults, 2 - sites for studying paleoseismic dislocations. Numbers indicate the calibrated age in thousand years.

отдельными разрывами и трещинами (или их системами), наследующими ослабленные зоны разломов древнего заложения. Значительно больше информации получено о следах позднеплейстоценголоценовых землетрясений и их вторичных эффектах.

Широкий спектр различных сейсмонарушений обнаружен в центральной части КП: в районе Имандровской неотектонической впадины. На ее западном фланге выделена структурнотектоническая зона, протяженностью более 10 км, активизация которой происходила на протяжении всего поздне- и послеледникового времени: 13500, 10300-7100, 2500 л.н. (Николаева и др., 2018). Моренный чехол нарушен субширотными сбросами амплитудой 0.6-1.3 м, в виде ступеней в скальных породах к югу от ж.д. ст. Уполокша. Геолого-геофизические наблюдения свидетельствуют об активизации в послеледниковье и голоцене зоны С3 простирания к 3 от озера Бабинская 
Имандра (Николаева и др., 2017, Родионов и др., 2018). По данным радиоуглеродных анализов время события $-6440 \pm 340$ кал л.н.

В Средней Карелии один из ключевых участков развития сейсмодислокаций - район г. Воттоваара (Лукашов, 2004; Шварев, Родкин, 2017). Он входит в состав крупного Воттоваара-Онежского сейсмолинеамента. Определена сдвиговая кинематика разлома по соотношению импульсных смешений блоков на крыльях разлома и последовательность нескольких сильных событий, в том числе относящихся к меж- и послеледниковому времени с возрастом около 8900 л.н.

Вуоксинская зона разломов (Никонов и др., 2014; Shvarev et al., 2018), маркируемая одноименной речной системой, представлена серией крупных разломов С3 простирания по самому западному из которых фиксируется восточный контакт Выборгского массива гранитов рапакиви с их раннепротерозойской рамой. Вдоль контакта при геологической съемке установлены смещения по разрывам С3 простирания, возникшие еще на стадии рифейского рифтогенеза и впоследствии неоднократно активизировавшиеся. Вблизи зоны разлома были изучены многочисленны дизъюнктивные (в скальных породах) и пликативные (в бассейновых отложениях) деформации, характеризуемые как следы позднечетвертичной и голоценовой тектонической и сейсмической активизации.

Разрывные нарушения поздне- и послеледниковго возраста и сопряженные сейсмодислокации обнаружены и в других районах восточной части ФСКЩ (рис. 1).

\section{Выводы}

Полученные материалы привели к следующим заключениям о характере послеледниковой тектоники и их пространственно-временных закономерностях:

- к настоящему времени на суше не выявлены протяженные разломы ( $\geq 70-100$ км), нарушающие позднечетвертичные или голоценовые осадки. Изучены разрывные нарушения ( $\mathrm{L} \leq 10-15$ км) со смещениями в первые см - десятки см, реже первые м;

- большая часть голоценовых разрывных нарушений пространственно наследует зоны древних разломов и лишь единичные разрывы являются новообразованиями;

- в структурно-динамическом отношении послеледниковые разрывы и сопряженные с ними очаги землетрясений тяготеют к новейшим грабенам Кандалакшскому, Онежскому, Ладожскому, а также к линейным сейсмогенерирующим зонам Мурманской и Вуоксинской. В целом эти закономерности соответст вуют диспозиции землетрясений за 100-300 лет;

- более активное разрывообразование и высокий уровень сейсмичности имели место в позднеледниковье и в раннем голоцене (14000-9000 л.н.). Такое временное распределение событий вероятно связано с затухающим гляциоизостатическим поднятием ФСКЩ и переходом от вертикально направленных сил гляциоизостазии к латеральным воздействиям. Действие гляциоизостазии, как фактора создания напряжений к настоящему времени практически исчерпало себя, тогда как тектонический фактор продолжает действовать.

Исследования проведены в рамках темы НИР ГИ КНЦ РАН № 0226-2019-0054.

\section{Литература}

1. Авенариус И.Г. Морфоструктурный анализ при изучении культурного и природного наследия ЗападноАрктического региона России. Паульсен. 2007. 197 с.

2. Балуев А.С., Журавлев В.А., Терехов Е.Н., Пржиялговский Е.С. Тектоника Белого моря и прилегающих территорий. (Объяснительная записка к «Карте тектоники Белого моря» масштаба 1:1500000). Отв. ред. М.Г. Леонов. М. Изд-во: ГЕОС. 2012. 104 с.

3. Верзилин Н.Н., Бобков А.А. По следам послеледниковых сейсмических проявлений в северо-восточном ограничении губы Чупа Белого моря в: Нестеров Е.М. (под ред.). Экскурсии в геологии: Коллективная монография V. СПб. Изд-во: РГПУ им. А.И. Герцена. 2009. С. 40-49.

4. Верзилин Н.Н., Бобков А.А., Кулькова М.А., Нестеров Е.М., Нестерова Л.А., Мадянова Н.П. О возрасте и образовании современного расчлененного рельефа севера Кольского п-ова // Вестник С-Пб. Ун-та. Сер. 7: Геол. Геогр. 2013. Т. 2. С. 79-93.

5. Землетрясения и микросейсмичность в задачах современной геодинамики Восточно-Европейской платформы. Кн. 1. Под ред. Н.В. Шарова, А.А. Маловичко, Ю.К. Щукина. Петрозаводск. 2007. 381 с. 
6. Лукашов А.Д. Геодинамика новейшего времени. В: Глубинное строение и сейсмичность Карельского региона и его обрамления. Под ред. Шаров Н.В. Петрозаводск: Карельский научный центр РАН. 2004. C. 150-191.

7. Николаева С.Б. Свидетельства сейсмических событий на побережье Мурмана в позднеледниковье и голоцене) // Изв. Русск. Географ. общ-ва. 2013. Т. 145. Вып. 4. С. 53-65.

8. Николаева С.Б., Лаврова Н.Б., Денисов Д.Б. Катастрофическое событие голоцена в донных осадках озер Кольского полуострова (СВ Фенноскандинавского щита) // ДАН. 2017. Т. 473. № 1. С. 88-92.

9. Николаева С.Б., Никонов А.А., Шварев С.В., Родкин М.В. Детальные палеосейсмогеологические исследования в бортовой зоне впадины озера Имандра (Кольский регион): новые подходы и результаты // Геология и геофизика. 2018. Т. 59. № 6. С. 866-880.

10. Никонов А.А. Сильнейшее на Мурманском побережье историческое землетрясение 1503 г. (по преданию двинских поморов) // Геодинамика и экология Баренц-региона в XXI веке. Матер. Всеросс. конференции. Архангельск. 15-17 сентября 2014 г. 2014. С. 189-192.

11. Никонов А.А. Землетрясение в Териберке 100 лет тому назад и вопрос о сейсмическом потенциале среднего сектора Мурманской сейсмогенной зоны // Труды Ферсмановской научной сессии ГИ КНЦ РАН. 2018 а. 15. С. 268-271.

12. Никонов А.А. Молодые продольные расколы в морфоструктуре Мурманской зоны разломов // Труды Ферсмановской научной сессии ГИ КНЦ РАН. 2018 б. № 15. С. 263-267.

13. Никонов А.А., Шварев С.В., Сим Л.А., Родкин М.В., Бискэ Ю.С., Маринин А.В. Скальные палеосейсмодеформации на Карельском перешейке (ключевой участок «Пешеры Иностранцева», Ленинградская область) // Докл. РАН. 2014. Т. 457. № 5. С. 591-596.

14. Никонов А.А., Шварев С.В. Сейсмолинеаменты и разрушительные землетрясения в российской части Балтийского щита: Новые решения для последних 13 тысяч лет // Материалы Междунар. конф. «Геологогеофизическая среда и разнообразные проявления сейсмичности». Нерюнгри: Изд-во Техн. ин-та (филиала) СВФУ. 2015. С. 243-251.

15. Никонов А.А., Полещук А.В., Зыков Д.С. О новейших разрывах и палеосейсмодислокациях в Онежской палеопротерозойскеой структуре Фенноскандинавского щита // Труды Карельского научного центра РAH. № 11. 2017. C. 3-18.

16. Родионов А.И., Николаева С.Б., Рязанцев П.А. Оценка возможностей георадиолокации при изучении сейсмогенных нарушений и деформаций в донных осадках (на примере озера Уполокшское, северовосток Фенноскандинавского щита) // Геодинамика и тектонофизика. 2018. Т. 9. № 4. С. 1189-1203.

17. Рыбалко А.Е., Корнеев, Ю.О. Государственный мониторинг состояния геологической среды шельфа на примере его проведения в Кандалакшском заливе Белого моря // Российские полярные исследования. T. 1. № 15. 2014. С. 10-16.

18. Шварев С.В. Признаки послеледниковых сейсмических воздействий в скальных породах и рыхлых отложениях юго-западного побережья Онежского озера // Современные проблемы четвертичной геологии и географии Северо-запада европейской части России и сопредельных стран: Материалы научной сессии (с участием иностранных специалистов), посвященной 100-летию со дня рождения Галины Сергеевны Бискэ (Петрозаводск, 9-10 марта 2017 г.). Под. ред. Т.С. Шелеховой. Петрозаводск: Карельский научный центр РАН. 2017. С. 48-52.

19. Шварев С.В, Родкин М.В. Структурная позиция и параметры палеоземлетрясений в районе горы Воттоваара (Средняя Карелия, восточная часть Фенноскандинавского щита) // Вопросы инженерной сейсмологии. Т. 44. № 2. 2017. С. 35-60.

20. Shvarev S.V., Nikonov A.A., Rodkin M.V., Poleshchuk A.V. The active tectonics of the Vuoksi Fault Zone in the Karelian Isthmus:parameters of paleoearthquakes estimated from bedrock and softsediment deformation features // Bulletin of the Geological Society of Finland. V. 90. 2018. P. 257-273. 